https://doi.org/10.46344/JBINO.2021.v010i01.26

\title{
COMPARATIVE EVALUATION OF ANTIBACTERIAL EFFECTS OF AQUEOUS AND METHANOLIC SEED EXTRACTS OF Citrillus lanatus Thunb.
}

\author{
'Sodipo O.A., ${ }^{2}$ Yakubu J., ${ }^{2 B e l l o ~ F . S . ~ a n d ~}{ }^{4}$ Gulani I.A. \\ 'Department of Clinical Pharmacology and Therapeutics, College of Medical Sciences, University of Maiduguri, Borno State. \\ 2Department of Pharmaceutical Microbiology, Faculty of Pharmacy, University of Maiduguri, Maiduguri, Borno State. \\ 3Department of Pure and Applied Chemistry, Faculty of Sciences, University of Maiduguri, Maiduguri, Borno State. \\ ${ }^{4}$ Department of Veterinary Microbiology, Faculty of Veterinary Medicine, University of Maiduguri, Maiduguri, Borno State
}

Email: jamesyakubu96@gmail.com

\begin{abstract}
The study aimed at evaluating the antimicrobial effects of aqueous and methanol seed extract of Citrillus lanatus, with the view of establishing scientific fact of the use of the plant for the treatment of microbial infections. The crude extracts of the seeds were obtained using distilled water and methanol respectively. The phytochemical and antibacterial potentials of Citrillus lanatus Thunb. seeds were evaluated. The seed extracts were tested for antibacterial activity using the agar well diffusion and the disc diffusion methods against clinical isolates of Gram positive bacteria (Staphylococcus aureus and Streptococcus pyogenes) and Gram negative bacteria (Escherichia coli, Klebsiella pneumoniae and Pseudomonas aeroginosa). The phytochemical test of the aqueous and methanolic seed extracts revealed the presence of flavonoids, cardenolides, cardiac glycosides, carbohydrates and terpenoids. The results of the disc diffusion method showed that the aqueous seed extract inhibited the growth of $K$. pneumoniae at concentrations of $300 \mathrm{mg} / \mathrm{ml}, 400 \mathrm{mg} / \mathrm{ml}$ and $500 \mathrm{mg} / \mathrm{ml}$ with zones of inhibitions of $9 \mathrm{~mm}, 12 \mathrm{~mm}$ and $14 \mathrm{~mm}$ respectively while the remaining bacteria showed resistance at all concentrations used. The methanolic seed extract inhibited the growth of $S$. aureus at concentrations of 200 $\mathrm{mg} / \mathrm{ml}, 300 \mathrm{mg} / \mathrm{ml}, 400 \mathrm{mg} / \mathrm{ml}$ and $500 \mathrm{mg} / \mathrm{ml}$ with zones of inhibitions of $7 \mathrm{~mm}, 10 \mathrm{~mm}, 15$ $\mathrm{mm}$ and $20 \mathrm{~mm}$ respectively; $S$. pyogenes at concentrations of $300 \mathrm{mg} / \mathrm{ml}, 400 \mathrm{mg} / \mathrm{ml}$ and $500 \mathrm{mg} / \mathrm{ml}$ with zones of inhibitions of $9 \mathrm{~mm}, 12 \mathrm{~mm}$ and $15 \mathrm{~mm}$ respectively, while $E$. coli, $K$. pneumoniae and Ps. aeroginosa showed no sensitivity. For the agar well diffusion method, all the tested bacteria were resistant at all the concentrations used with the exception of $S$. aureus which was sensitive to the methanolic seed extract at concentrations of $100 \mathrm{mg} / \mathrm{ml}$, $200 \mathrm{mg} / \mathrm{ml}, 300 \mathrm{mg} / \mathrm{ml}, 400 \mathrm{mg} / \mathrm{ml}$ and $500 \mathrm{mg} / \mathrm{ml}$ with zones of inhibitions of $11 \mathrm{~mm}, 13$ $\mathrm{mm}, 15 \mathrm{~mm}, 17 \mathrm{~mm}$ and $19 \mathrm{~mm}$ respectively. S. aureus showed the highest sensitivity towards the extract among the bacteria used with the methanolic extract exhibiting a higher antibacterial activity. The result obtained in this study does not justify the traditional claim of C. lanatus as an antibacterial agent.
\end{abstract}

Keyword: Citrillus lanatus, phytochemicals, antibacterial, agar well diffusion, disc diffusion 


\section{INTRODUCTION}

For centuries man has effectively used various components of plants or their extracts for the treatment of many diseases, including bacterial infections. Medicinal plants are known to contain in one or more of their organs substances that can be used for therapeutic purposes or as precursor for synthesis of useful drugs (Sofowora, 2008). Plants are considered not only as dietary supplement to living organisms but also traditionally used for treating many health problems. Over $60 \%$ of the world human population, $80 \%$ in developing countries depend directly on plants for their medicinal purposes (Dhillion et al., 2002).

Phytochemicals are non-nutritive plant chemicals that have protective or disease preventive properties. Plants produce these chemicals to protect themselves, but recent research demonstrates that many phytochemicals can protect humans against diseases. Fruits and vegetables have been recognized as natural sources of various bioactive compounds (Pennington and Fisher, 2010) which could be attributed to their phytoconstituents such as flavonoids, anthocyanins, phenolic compounds, vitamins $C$ and $E$, dietary fiber and carotenoids present in fruits and vegetables (Gonzalez-Aguilar et al., 2008). Many plants extracts have been shown to inhibit the growth of microorganisms. These extracts consist of chemicals and are usually considered to play a role in defence reactions of plants against infections by pathogenic microorganisms (Fawcett and Spencer, 1976).
Citrillus lanatus (Fig. 1) commonly known as watermelon, is a popular fruit in many parts of the world. It belongs to the family Cucurbitaceae, a vine-like flowering plant originally from Africa. Cucurbitaceae is a family that comprises approximately 120 genera and over 900 species which are vastly distributed in tropical and subtropical regions of Asia, Australia, Africa and America (Rubatzky and Yamaguchi, 1997). The fruit comes in various shapes, sizes and rind pattern (Wehner, 2008). Water constitutes about $92 \%$ of the total fruit weight. Watermelon is grown in the tropical and subtropical areas worldwide for its large edible fruit which is a special kind of berry with a hard rind and no internal division. Watermelon seeds are a source of protein, B vitamins, minerals (such as magnesium, zinc, iron, copper, sodium, phosphorus, manganese, potassium) and fat among others (Vandermark, 2011; Collins et al., 2007). A study carried out by Varghese et al. (2013) showed that watermelon seeds contain various amounts of carbohydrate, phenol, flavonoids, protein, fiber, phosphorous and iron. Also, proximate analysis of the seeds (Oyeleke et al., 2012) revealed very high fat content (47.9\%) followed by protein (27.4\%) and carbohydrate (9.9\%). A study carried out by Adunola et al. (2015) revealed that the kind of solvent employed as well as the conditions of extraction influence the efficacy of the extract against specific test organisms.

Indiscriminate use of antimicrobials and fake substandard drugs has led to widespread resistance to commonly used 
antibiotics. In addition, the high cost of conventional drugs has led many people to seek for alternative inexpensive sources of treatment. Thus, antimicrobial compounds found in plants are now the focal point of interest in the treatment of infectious diseases.

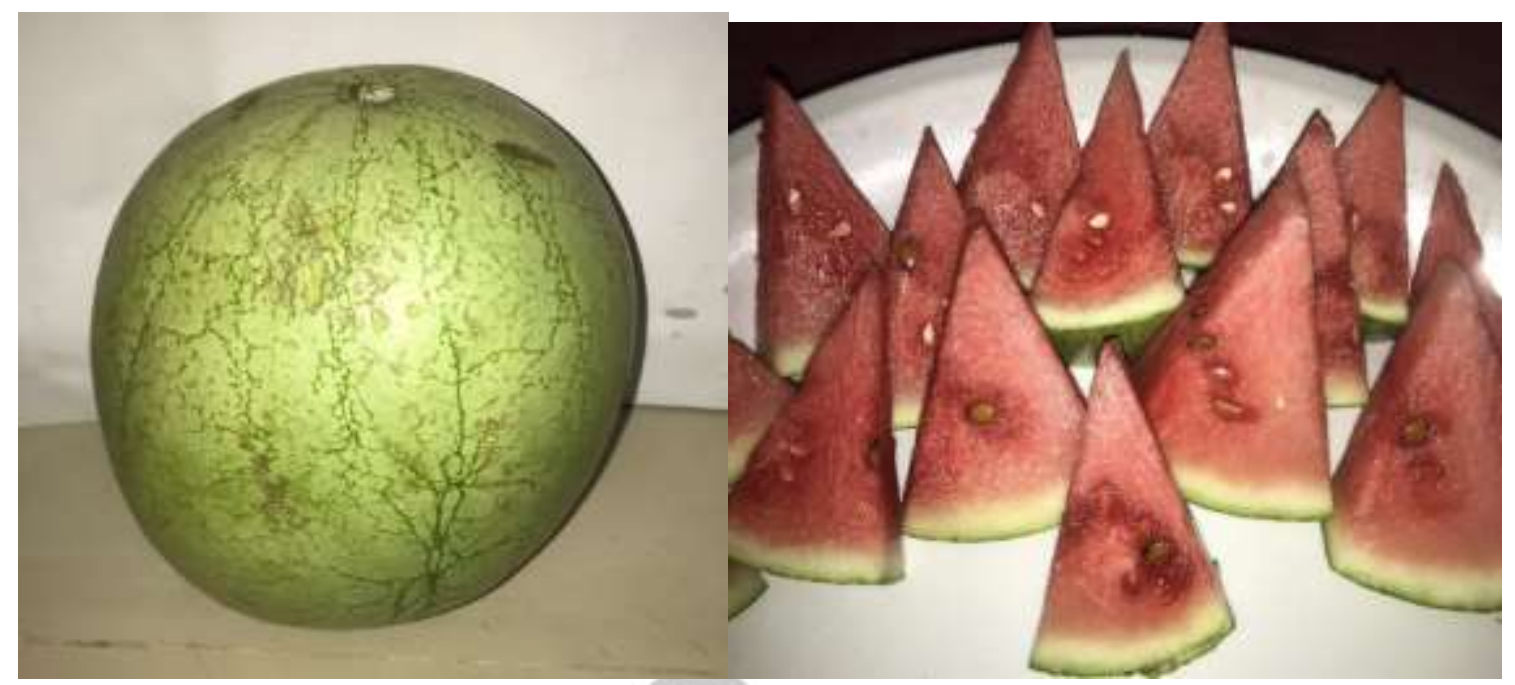

Fig. 1: Citrillus lanatus Thunb. Fruit (Whole and Sliced)

\section{MATERIALS AND METHODS}

\section{Materials}

The materials used include: reflux extractor, weighing balance, desiccator, test tubes, filter paper, methanol (Analar grade), measuring cylinder, mortar and pestle, stainless steel trays, dropper, sample containers, distilled water, retort stand, beaker, syringes, muslin cloth, petri dishes, nutrient agar, antibiotic discs, forceps, circular discs, Gram negative and Gram positive bacteria, cotton wool, nutrient broth, transparent ruler and a cork-borer.

Source, Collection and Identification of Plant Materials

The seeds of Citrillus lanatus were obtained from fresh retailed watermelon fruit from Custom Market, Maiduguri, Borno State, Nigeria. The plant was identified and authenticated by Prof. S.S. Sanusi, a Plant Taxonomist in the Department of Biological
Sciences, Faculty of Science, University of Maiduguri, Nigeria. A voucher specimen was prepared (UM/FPH/03/001/006) and deposited in the Faculty of Pharmacy Herbarium.

\section{Preparation of the Plant Extract}

The seeds of $C$. lanatus were dried under shade for seven days. The seeds were finely ground into powder using a wooden mortar and pestle. The powdered seeds were stored in a closed container and stored in a desiccator prior to extraction, and the solvents used for the extraction were distilled water and methanol (Analar grade).

\section{Aqueous Extraction}

The method used for the extraction was reflux. $250 \mathrm{~g}$ of the powdered watermelon seeds was introduced into a $5 \mathrm{~L}$ conical flask of the reflux extractor, 2 L distilled water was added and it was refluxed for 2 
h. The extracted sample was then decanted, filtered using Whatman filter paper (No. 11) and dried on a water bath. It was then stored in a desiccator.

\section{Extraction}

The method used for the extraction was also reflux. $280 \mathrm{~g}$ of the powdered watermelon seed was introduced into a $5 \mathrm{~L}$ conical flask of the reflux extractor, $2 \mathrm{~L}$ of methanol was added and it was refluxed for $2 \mathrm{~h}$. The extracted sample was decanted, filtered using Whatmann filter paper (No. 11) and dried on a water bath. It was then stored in a desiccator.

\section{Phytochemical Screening}

A little quantity of each of the extracts were subjected to phytochemical tests to determine the presence of the following: alkaloids, flavonoids, saponins, anthraquinones, terpenoids, phlobatannins, soluble starch, cardiac glycosides and carbohydrates as described by Vishnoi (1979); Evans (2009); Sofowora (2008); Brian and Turner (1975); Markham (1982); Silver et al. (1998).

\section{Antibacterial Studies of the Aqueous and Methanolic Seed Extracts of Citrillus Ianatus}

\section{Test Bacteria}

For the antibacterial activity study, a total of five bacteria were used; three Gram negative and two Gram positive bacteria. The Gram negative bacteria used include: Escherichia coli, Klebsiella pneumoniae and Pseudomonas aeroginosa, while the Gram positive bacteria used were: Staphylococcus aureus and Streptococcus pyogenes. These organisms were obtained from the Department of Medical Microbiology, University of Maiduguri Teaching Hospital, Maiduguri, Nigeria.

\section{Sterilization of the Materials}

The media were sterilized in a portable autoclave at $121^{\circ} \mathrm{C}$ for 15 minutes while the pipettes and other glass wares were sterilized by dry heat in a hot air oven at $160^{\circ} \mathrm{C}$ for 1 hour. The cork-borer was sterilized by autoclaving and then using open flame subsequently during the boring process. The circular discs were sterilized in the petri dish using hot air oven at $160^{\circ} \mathrm{C}$ for 1 hour.

\section{Antibacterial Sensitivity Tests}

Two methods were used for the antibacterial sensitivity test, these are: agar well diffusion and the disc diffusion methods.

\section{Agar Well Diffusion Method}

The agar well diffusion method by Kudi et al. (1999); Ogundipe et al. (2000) as reported by lsa et al. (2014) was used to determine the growth inhibition of the test organisms by the plant extracts. The tests were carried out using different concentrations; 100, 200, 300, 400 and 500 $\mathrm{mg} / \mathrm{ml}$ which were prepared by dissolving the aqueous extract in water while the methanolic extract was dissolved in methanol. Nutrient agar was prepared according to the manufacturer's specification; $25 \mathrm{ml}$ each was poured into sterile petri-dishes and were allowed to dry and solidify.

Using a sterile cork-borer of $9 \mathrm{~mm}$ diameter, three holes per plate were made in the solidified agar and were inoculated with $0.5 \mathrm{ml}$ suspension of the bacteria. Thereafter, the wells were filled with the prepared concentrations of the extract solutions using sterile syringes. These were done in triplicates and the plates were

\section{January Edition | www.jbino.com | Innovative Association}


incubated at $37^{\circ} \mathrm{C}$ for $24 \mathrm{~h}$ and the relative susceptibility of each bacterium to the extract as indicated by clear zones of growth inhibition (zone of inhibition) around the wells were measured with a transparent meter rule in millimeters and recorded. The standard antimicrobial discs used were Ciprofloxacin (5 $\mu g)$, Gentamycin $(10 \mu \mathrm{g})$, Erythromycin $(15 \mu \mathrm{g})$ [Oxoid Ltd., Basingstoke, Hampshine England].

\section{Disc Diffusion Method}

The agar disc diffusion method by $\mathrm{Xu}$ and Lee (2001); Mahasneh (2002) was used to determine the growth inhibition of the test organisms by the plant extract. Sterilized filter paper discs (6 $\mathrm{mm}$ in diameter) were impregnated in appropriate concentrations of the seed extract $(100$, 200, 300, 400 and $500 \mathrm{mg} / \mathrm{ml}$ ). The discs (made from Whatman No. 1 filter paper) were allowed to absorb the extracts as described by Mahasneh (2002). The agar plates were aseptically inoculated with broth cultures of the test microorganisms using sterile pipettes and the plates allowed to dry. The discs containing the plant extract were transferred using flamed but cooled forceps onto the surface of the seeded agar plates. They were sufficiently spaced to prevent the resulting zones of clearing from overlapping. The plates were then incubated for $24 \mathrm{~h}$ at $37^{\circ} \mathrm{C}$. After $24 \mathrm{~h}$, the zone of inhibition around each disc was measured and recorded in $\mathrm{mm}$ using a transparent meter rule.

\section{Statistical Analysis}

The statistical analyses were carried out using GraphPad Statistical package,
Version 5.0 (GraphPad ${ }^{\circledR}, 2007$ ). The mean and standard error of mean (SEM) as parameters were determined and the mean values of the zones of inhibition of the seed extracts were compared with that of the standard drugs.

\section{RESULTS}

\section{Phytochemical Studies}

The colour, texture and percentage yield of the extracts from the reflux extraction are presented in Table 1. The colour of the aqueous and methanolic extracts were coffee brown, the texture of both extracts was crystalline. The weights of the aqueous and methanolic extracts were $250 \mathrm{~g}$ and $280 \mathrm{~g}$ with a percentage yield of 12.68 $\% \mathrm{w} / \mathrm{w}$ and $5.64 \% \mathrm{w} / \mathrm{w}$ respectively. The results of the aqueous and methanolic extracts showed the presence of flavonoids, terpenoids, cardiac glycosides, cardenolides and carbohydrates as presented in Table 2.

Antimicrobial Susceptibility Tests of the Aqueous and Methanolic Seed Extracts of C. lanatus

\section{The Agar Well Diffusion Method}

The results of the in vitro antimicrobial susceptibility test of both the aqueous and methanolic seed extracts of $C$. lanatus using the agar well diffusion method are shown in Tables 3 and 4 respectively. The aqueous seed extract did not inhibit the growth of all the bacteria (Staphylococcus aureus, Streptococcus pyogenes, Escherichia coli, Klebsiella pneumoniae and Pseudomonas aeroginosa) at all concentrations $(100,200,300,400$ and 500 $\mathrm{mg} / \mathrm{ml}$ ).

The methanolic seed extract inhibited the growth of $S$. aureus at concentrations of 
$100 \mathrm{mg} / \mathrm{ml}, 200 \mathrm{mg} / \mathrm{ml}, 300 \mathrm{mg} / \mathrm{ml}, 400$ $\mathrm{mg} / \mathrm{ml}$ and $500 \mathrm{mg} / \mathrm{ml}$ with zones of inhibition of $11.00 \pm 0.00 \mathrm{~mm}, 13.00 \pm 0.00 \mathrm{~mm}$, $15.00 \pm 0.00 \mathrm{~mm}, \quad 17.00 \pm 0.00 \mathrm{~mm}$ and $19.00 \pm 0.00 \mathrm{~mm}$ respectively, while $S$. pyogenes, E. coli, K. pneumoniae and Ps. aeroginosa showed no sensitivity.

\section{The Disc Diffusion Method}

The results of the in vitro antimicrobial susceptibility test of both the aqueous and methanolic seed extracts of $C$. lanatus using the disc diffusion method are shown in Tables 5 and 6 respectively. The result showed that the aqueous seed extract did not inhibit the growth of $S$. aureus, $S$. pyogenes, E. coli and Ps. aeroginosa at all the concentrations $(100,200,300,400$ and $500 \mathrm{mg} / \mathrm{ml}$ ), while the growth of $K$. pnemoniae was inhibited at concentrations of $300 \mathrm{mg} / \mathrm{ml}, 400 \mathrm{mg} / \mathrm{ml}$ and $500 \mathrm{mg} / \mathrm{ml}$ with zones of inhibition of 9 $\mathrm{mm}, 12 \mathrm{~mm}$, and $14 \mathrm{~mm}$ respectively while it showed no inhibition at concentrations of $200 \mathrm{mg} / \mathrm{ml}$ and $100 \mathrm{mg} / \mathrm{ml}$.

The methanolic seed extract inhibited the growth of $S$. aureus at concentrations of $200 \mathrm{mg} / \mathrm{ml}, 300 \mathrm{mg} / \mathrm{ml}, 400 \mathrm{mg} / \mathrm{ml}$ and 500 $\mathrm{mg} / \mathrm{ml}$ with zones of inhibition of $7 \mathrm{~mm}, 10$ $\mathrm{mm}, 15 \mathrm{~mm}$ and $20 \mathrm{~mm}$ respectively, while at $100 \mathrm{mg} / \mathrm{ml}$ it showed no inhibition. S. pyogenes also showed sensitivity at concentrations of $300 \mathrm{mg} / \mathrm{ml}, 400 \mathrm{mg} / \mathrm{ml}$ and $500 \mathrm{mg} / \mathrm{ml}$ with zones of inhibition of 9 $\mathrm{mm}, 12 \mathrm{~mm}$ and $15 \mathrm{~mm}$ respectively. $E$. coli, K. pneumoniae and Ps. aeroginosa showed no sensitivity to the methanolic seed extract at all concentrations (100, $200,300,400$ and $500 \mathrm{mg} / \mathrm{ml}$ ).

For the standard antibiotic discs used, Ciprofloxacin ( $5 \cup \mathrm{g}$ ) inhibited the growth of S. aureus, S. pyogenes, E. coli, K. pneumoniae and Ps. aeroginosa with zones of inhibition of $10 \mathrm{~mm}, 21 \mathrm{~mm}, 34$ $\mathrm{mm}, 25 \mathrm{~mm}$ and $25 \mathrm{~mm}$ respectively; Gentamycin (10 ug) inhibited the growth of S. pyogenes, E. coli, K. pneumoniae and Ps. aeroginosa with zones of inhibition of 21 $\mathrm{mm}, 20 \mathrm{~mm}, 20 \mathrm{~mm}$ and $10 \mathrm{~mm}$ respectively, while it did not inhibit the growth of $S$. aureus. Erythromycin (15 ug) inhibited the growth of $S$. pyogenes, E. coli and $K$. pneumoniae with zones of inhibition of $20 \mathrm{~mm}, 9 \mathrm{~mm}$ and $11 \mathrm{~mm}$ respectively, while S. aureus and Ps. aeroginosa showed no sensitivity.

Table 1. The Weight, Colour, Texture and Percentage yield of the Aqueous and Methanolic Extracts of $C$. lanatus Seeds from the Reflux Extraction Process

\begin{tabular}{lll}
\hline Parameters & Aqueous Extract & Methanolic Extract \\
\hline Weight of the Powder $(\mathrm{g})$ & 250 & 280 \\
Weight of the Extract $(\mathrm{g})$ & 31.69 & 15.79 \\
Colour & Coffee brown & Coffee brown \\
Texture & Crystalline & Crystalline \\
Percentage yield $(\%){ }^{w} / w$ & 12.68 & 5.64 \\
\hline
\end{tabular}


Table 2. Phytochemistry of the Aqueous and Methanolic Extracts of $C$. lanatus Seeds

\section{SN Plant Constituents/Test RESULTS (Aqueous and Observation}

Methanolic extracts)

1. Carbohydrates

i. General test (Molisch's test)

ii. Test for Monosaccharide (Barfoed's

$+$ test)

iii. Test for Free reducing sugar (fehling's test)

iv. Test for Combined reducing sugar

v. Test for Ketoses

2. Test for Alkaloids

i. Dragendorff's reagent

ii. Mayer's reagent

3. Test for Flavonoids

i. Shinoda's test

ii. Ferric chloride test

iii. Lead Ethanoate test

iv. Sodium Hydroxide test

4. Test for Saponins

i. Frothing test

5. Test for Anthraquinones

i. Free Anthraquinone test (Borntrager's test)

ii. Combined

(Borntrager's test)

6. Test for Terpenoids

7. Test for Tannins

i. Ferric chloride test

ii. Lead acetate test

8. Test for Phlobatannins

9. Test for Cardiac glycosides

i. Salkowaski's test

ii. Liebermann-Burchard's test

10. Test for Soluble starch

11. Test for Cardenolides

i. Keller-killiani's test
Anthraquinones

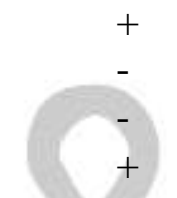

Pink colour

No colour change

No colour change

Colourless

No foam formed

No red colour formed

No red colour formed

Violet colour

No green colour formed

No white precipitate formed

No colour change

$+\quad$ Bluish-green colour

$+\quad$ Reddish brown colour at interphase

No colour change

Brown ring at the interphase

\section{Key}

$-=$ Absent $\quad+=$ Present 
Table 3 Antibacterial Activity of the Aqueous Seed Extract of $C$. lanatus using the Agar Well Diffusion Method

\begin{tabular}{|c|c|c|c|c|c|c|c|c|}
\hline \multirow[t]{2}{*}{$\begin{array}{l}\text { Organisms } \\
\text { Used }\end{array}$} & \multicolumn{5}{|c|}{$\begin{array}{l}\text { Concentrations }(\mathrm{mg} / \mathrm{ml}) \text { and diameter of zones of } \\
\text { inhibition }(\mathrm{mm}), \pm \text { SEM }\end{array}$} & \multicolumn{3}{|c|}{ Standard Drugs } \\
\hline & $\begin{array}{l}100 \\
\mathrm{mg} / \mathrm{ml}\end{array}$ & $\begin{array}{l}200 \\
\mathrm{mg} / \mathrm{ml}\end{array}$ & $\begin{array}{l}300 \\
\mathrm{mg} / \mathrm{ml}\end{array}$ & $\begin{array}{l}400 \\
\mathrm{mg} / \mathrm{ml}\end{array}$ & $\begin{array}{l}500 \\
\mathrm{mg} / \mathrm{ml}\end{array}$ & Cipro & Genta & Erythro \\
\hline S. aureus & $0.00 \pm 0.00$ & $0.00 \pm 0.00$ & $0.00 \pm 0.00$ & $0.00 \pm 0.00$ & $0.00 \pm 0.00$ & $10.00 \pm 0.00$ & $0.00 \pm 0.00$ & $0.00 \pm 0.00$ \\
\hline S. pyogenes & $0.00 \pm 0.00$ & $0.00 \pm 0.00$ & $0.00 \pm 0.00$ & $0.00 \pm 0.00$ & $0.00 \pm 0.00$ & $21.00 \pm 0.00$ & $21.00 \pm 0.00$ & $20.00 \pm 0.00$ \\
\hline E. coli & $0.00 \pm 0.00$ & $0.00 \pm 0.00$ & $0.00 \pm 0.00$ & $0.00 \pm 0.00$ & $0.00 \pm 0.00$ & $34.00 \pm 0.00$ & $20.00 \pm 0.00$ & $9.00 \pm 0.00$ \\
\hline K. pneumoniae & $0.00 \pm 0.00$ & $0.00 \pm 0.00$ & $0.00 \pm 0.00$ & $0.00 \pm 0.00$ & $0.00 \pm 0.00$ & $25.00 \pm 0.00$ & $20.00 \pm 0.00$ & $11.00 \pm 0.00$ \\
\hline P. aeruginosa & $0.00 \pm 0.00$ & $0.00 \pm 0.00$ & $0.00 \pm 0.00$ & $0.00 \pm 0.00$ & $0.00 \pm 0.00$ & $25.00 \pm 0.00$ & $10.00 \pm 0.00$ & $0.00 \pm 0.00$ \\
\hline
\end{tabular}

Key: Cipro $=$ Ciprofloxacin

Genta $=$ Gentamycin

Erythro $=$ Erythromycin

$\mathrm{SEM}=$ Standard error of mean

Table 4. Antibacterial Activity of the Methanolic Seed Extract of C. lanatus using the Agar Well Diffusion Method Organisms Concentrations $(\mathrm{mg} / \mathrm{ml})$ and diameter of zones of inhibition Standard Drugs

Used

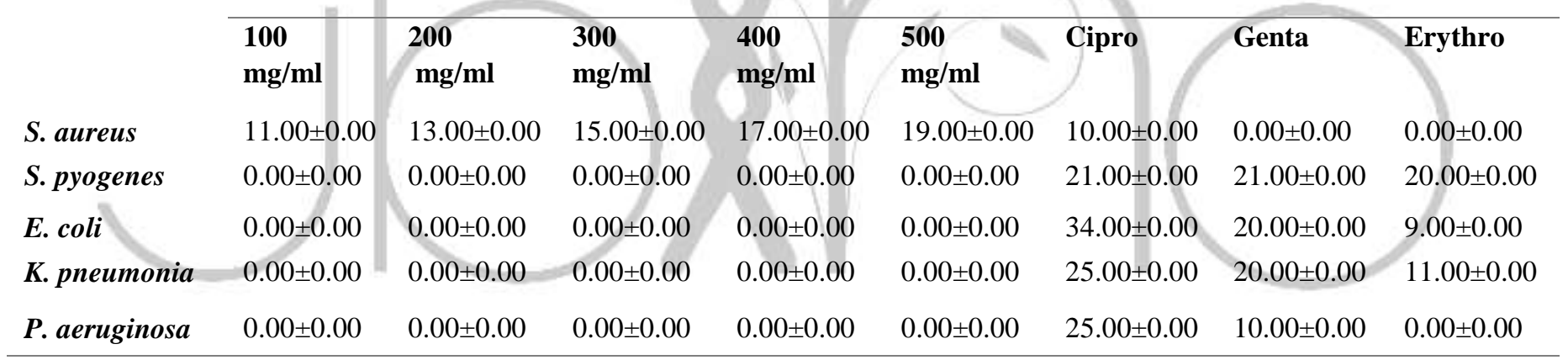

Key: Cipro= Ciprofloxacin

Genta $=$ Gentamycin

Erythro $=$ Erythromycin

$\mathrm{SEM}=$ Standard error of mean

Table 5. Antibacterial Activity of the Aqueous Seed Extract of $C$. lanatus using the Disc Diffusion Method

\begin{tabular}{|c|c|c|c|c|c|c|c|c|}
\hline \multirow[t]{2}{*}{$\begin{array}{l}\text { Organisms } \\
\text { Used }\end{array}$} & \multicolumn{5}{|c|}{$\begin{array}{l}\text { Concentrations }(\mathrm{mg} / \mathrm{ml}) \text { and diameter of zones of inhibition } \\
(\mathrm{mm})\end{array}$} & \multicolumn{3}{|c|}{ Standard Drugs } \\
\hline & $100 \mathrm{mg} / \mathrm{ml}$ & $200 \mathrm{mg} / \mathrm{ml}$ & $300 \mathrm{mg} / \mathrm{ml}$ & $400 \mathrm{mg} / \mathrm{ml}$ & $500 \mathrm{mg} / \mathrm{ml}$ & Cipro & Genta & Erythro \\
\hline S. aureus & 0 & 0 & 0 & 0 & 0 & 10 & 0 & 0 \\
\hline S. pyogenes & 0 & 0 & 0 & 0 & 0 & 21 & 21 & 20 \\
\hline E. coli & 0 & 0 & 0 & 0 & 0 & 34 & 20 & 9 \\
\hline K. pneumonia & 0 & 0 & 9 & 12 & 14 & 25 & 20 & 11 \\
\hline
\end{tabular}



P. aeruginosa
0
0
0
0
25
10
0

Key: Cipro= Ciprofloxacin

Genta $=$ Gentamycin

Erythro $=$ Erythromycin

Table 6. Antibacterial Activity of the Methanolic Seed Extract of C. lanatus using the Disc Diffusion Method

\begin{tabular}{|c|c|c|c|c|c|c|c|c|}
\hline \multirow[t]{2}{*}{$\begin{array}{l}\text { Organisms } \\
\text { Used }\end{array}$} & \multicolumn{5}{|c|}{$\begin{array}{l}\text { Concentrations }(\mathrm{mg} / \mathrm{ml}) \text { and diameter of zones of inhibition } \\
(\mathrm{mm})\end{array}$} & \multicolumn{3}{|c|}{ Standard Drugs } \\
\hline & $100 \mathrm{mg} / \mathrm{ml}$ & $200 \mathrm{mg} / \mathrm{ml}$ & $300 \mathrm{mg} / \mathrm{ml}$ & $400 \mathrm{mg} / \mathrm{ml}$ & $500 \mathrm{mg} / \mathrm{ml}$ & Cipro & Genta & Erythro \\
\hline S. aureus & 0 & 0 & 10 & 15 & 20 & 10 & 0 & 0 \\
\hline S. pyogenes & 0 & 0 & 9 & 12 & 15 & 21 & 21 & 20 \\
\hline E. coli & 0 & 0 & 0 & 0 & 0 & 34 & 20 & 9 \\
\hline K. pneumoniae & 0 & 0 & 9 & 0 & 0 & 25 & 20 & 11 \\
\hline P. aeroginosa & 0 & 0 & 0 & 0 & 0 & 25 & 10 & 0 \\
\hline
\end{tabular}

Key: Cipro= Ciprofloxacin

Genta $=$ Gentamycin

Erythro $=$ Erythromycin

\section{DISCUSSION}

Various plant extracts have been demonstrated to possess antibacterial activity against microbial pathogens (Mahesh and Satish, 2008). The antimicrobial activity observed could be due to the various phytochemicals present. In this study, the composition and antibacterial properties of the aqueous and methanolic seed extracts of $C$. lanatus were examined. The extracts showed the presence of flavonoids, terpenoids, cardiac glycosides, cardenolides and carbohydrate. These phytochemicals have been shown to possess antimicrobial activity (Compean and Ynalvez, 2014). Plants containing toxic glycosides as reported by Aboaba et al. (2006) can get hydrolysed to release phenolics which are toxic to microbial pathogens. Flavonoids have been found to show in vitro antimicrobial activity against a wide range of bacteria. This ability is attributed to their ability to complex with extracellular and soluble protein as well as with the bacterial cell wall (Cowan, 1999). Terpenoids are terpenes to which additional elements such as oxygen have been added (Cowan, 1999). Terpenoids have been found to possess antimicrobial activity (Amara et al., 1998; Mendoza et al., 1997). The mechanism of action of terpenoids is not fully understood, but it is been stipulated to involve membrane disruption by the lipophilic compounds (Mendoza et al., 1997). Therefore, the sensitivity shown by the bacteria in this study could probably be attributed to the presence of the above phytochemicals.

Previous studies carried out on watermelon seeds showed the presence of alkaloids, tannins, and saponins, which have been found to possess antibacterial activity against various bacteria (Compean and 2021 January Edition | www.jbino.com | Innovative Association 
Ynalvez, 2014). However, in this study, all these phytochemicals were found to be absent. This as reported by Adunola et al. (2015) could be due to the kind of solvents employed as well as the conditions for extraction which can influence the efficacy of the extract against the test organisms. This was evident in a study carried out by Adunola et al. (2015) in which the chloroform extracts of $C$. lanatus seed also showed the absence of saponins, tannins and alkaloids, while the aqueous extract showed the absence of only alkaloids. The methanolic extract however showed the presence of all the phytochemicals tested. Another scenario for the effect of extraction process can be seen in the study carried out by Braide et al. (2012) using ethanolic, methanolic and aqueous extraction in the absence of heat which showed the presence of all the phytochemicals and all the test microorganisms used showed susceptibility. According to Essien et al. (2009) methanol has the ability of dissolving fat during extraction process and watermelon is known to contain a lot of fat (about $40 \%$ ), thus this could have resulted in the low antibacterial activity exhibited by the methanolic extract against the tested microorganisms.

Another reason for the absence of alkaloids, saponins and tannins, in this study may be due to the fact that the composition of these secondary metabolites varies from species to species, climatic conditions and physiological state of development of the endemic plants (Hussain and Deeni, 1991).
The lack of sensitivity showed by some of the bacteria used in this study may therefore be attributed to the absence of some the above phytochemicals, and the poor antibacterial activity obtained (i.e. the low zones of inhibitions) may also be due to the low concentrations of the phytochemicals that were found to be present according to Braide et al. (2012).

In this study, the Gram-positive bacteria showed more sensitivity than the Gramnegative bacteria to the seed extract. Gram-negative bacteria have outer phospholipid membrane carrying the structural lipopolysaccharides components. This makes the cell wall impermeable to antimicrobial chemical substances. The Gram-positive bacteria on the other hand are more susceptible because the peptidoglycan constituting the outer layer is not an effective permeability barrier. Therefore, the walls of Gram-negative bacteria act as a diffusional barrier making them less susceptible to antimicrobial agents than Gram-positive bacteria (Nostro et al., 2000; Hodges, 2002).

$K$. pneumoniae was the only Gramnegative bacteria that showed sensitivity to the extract. This aligns with the report of Braide et al. (2012) in which K. pneumoniae was susceptible to the aqueous seed extract of C. lanatus. S. aureus showed the highest zone of inhibition among all the tested microorganisms. This is in concordance with the reports of Adunola et al. (2015); Braide et al. (2012); Essien et al. (2009) in which S. aureus exhibited the highest zones of inhibition among other tested microorganisms. This shows that $S$. 
aureus is the most susceptible microorganism to the antibacterial effect of $C$. lanatus seed extract. The methanolic seeds extract showed better activity which is in contrast to the study of Braide et al. (2012). This may probably imply that more of the phytochemicals were extracted with methanol.

The C. lanatus seed extracts exhibited low antibacterial activity than that of the standard antibiotics used, with the exception of $S$. aureus which was resistant to gentamycin and erythromycin but showed sensitivity towards the methanolic seed extract at concentrations of 500 $\mathrm{mg} / \mathrm{ml}, 400 \mathrm{mg} / \mathrm{ml}, 300 \mathrm{mg} / \mathrm{ml}$ and 200 $\mathrm{mg} / \mathrm{ml}$. This resistance to gentamycin is in accordance to the study carried out by Dowding (1977) in which clinical isolates of S. aureus were shown to be resistant to gentamycin. Also the resistance of $S$. aureus to erythromycin is in agreement with a study carried out by Vlkova et al. (2008). Ps. aeroginosa also showed resistance to erythromycin in accordance with a study conducted by Morita et al. (2013).

\section{Conclusion}

In this study, the aqueous and methanolic seed extracts of $C$. lanatus showed the presence of flavonoids, terpenoids, carbohydrates, cardenolides and cardiac glycosides. The extracts showed poor activity towards some of the tested microorganisms while some showed no sensitivity at all. The Gram-positive bacteria showed more sensitivity than the Gramnegative bacteria with the methanolic extract exhibiting more activity.
This study does not justify the potential of $C$. lanatus as an antibacterial agent but further investigation should be done as it could serve as a source of drug for some microbial infections as it showed the presence of some useful phytochemicals.

\section{REFERENCES}

Aboaba O.O., Smith S.I. and Olude F.O. (2006). Antibacterial effect of edible plant extract on E.coli 0157. Journal of Nutrition, 5(4): 325-327.

Adunola A.T., Chidimma A.L. Olatunde D.S. and Peter O.A. (2015). Antibacterial activity of watermelon (Citrillus lanatus) seed against selected microorganisms. African Journal of Biotechnology, 14(14): $1224-1229$.

Amara J.A. Ekins, A. Rickards, S.R. and Knowles K.R. (1998). Effect of selected monoterpenes on methane oxidation, dentrification and aerobic metabolism of bacteria on pure culture. Applied Environmental Microbiology, 64: 520-525.

Braide W, Odiong I.J. and Oranusi S. (2012). Phytochemical and antibacterial properties of the seed of watermelon (Citrillus lanatus). Prime Journal of Microbiology Research, 2(3): 99-104.

Brian K.R. and Turner T.D. (1975). The Practical Evaluation of Pharmaceuticals. J. Wright Science Technical, Bristol, 1st Edition. pp. 190-191.

Compean K.L. and Ynalvez R.A. (2014). Antimicrobial activity of plant secondary 
metabolites: A Review. Research Journal of Medicinal Plants, 8: 204-213.

Cowan M.M. (1999). Plant products as antimicrobial agents. Clinical Microbiology Review, 12: 564-582.

Dhillion S.S., Svarstad H., Amundsen C. and Bugge H.C. (2002). Bioprospecting: Effects on environment and development. A Journal of Human Environment, 31 (6): 491493.

Dowding J.E. (1977). Mechanisms of Gentamicin resistance in Staphylococcus aureus. Antimicrobial Agents and Chemotherapy, 11 (1): 47-50.

Essien E.B., Amuefule O.I. and Ihenacho, E. (2009). Proximate analysis and physicochemical properties of watermelon seeds. Nigerian Journal of Biochemistry and Molecular Biology, 24(2): 6-10.

Evans C.W. (2009). Trease and Evans Textbook of Pharmacognosy. 16th ed. Saunders Elsevier. Edinburgh London New York Philadelphia St Louis Sydney Toronto, Printed In China. pp. 196-197,225-227,229232,561 .

Fawcett C.H. and Spencer D.M. (1976). Plant chemotherapy with natural products. Annual Revised Phytopathology, 8: 403418.

Gonzalez-Aguilar G., Robles-Sanchez R.M., Martinez-Tellez M.A., Olivas G.I., AlvarezParilla E. and De La Rosa L.A. (2008). Bioactive compounds in fruits: health benefits and effect of storage conditions. Stewart Postharvest Review, 4(3): 1-10.

GraphPad. (2007). GraphPad Statistical Software Package. GraphPad Prism®, Version 5.0.

Hodges N. (2002). Pharmaceutical application of microbiological techniques. The science of dosage form design. Aulton, M.E. 2nd edition. Harcourt Publishers Ltd., London. p. 606.

Hussain H.S.N. and Deeni Y.Y. (1991). Plants in Kano ethnomedicine; screening for antimicrobial activity and alkaloids. International Journal of Pharmacognosy, 29: 51-56.

Isa M.O., Makinde A.M. and Akinpelu A.B. (2014). Secondary metabolites and antimicrobial activities of selected Mosses at the Obafemi Awolowo University, lle-lfe, Nigeria. International Journal of Scientific Research, 4(1): 49-60.

Kudi A.C., Umoh J.U., Eduvic L.D. and Getu, J. (1999). Screening of some Nigerian medicinal plants for antimicrobial activity. Journal of Ethnopharmacology, 67: 225228.

Mahasneh A. (2002). Screening of some indigenous Qatari medicinal plants for antimicrobial activity. Phytotherapeutic Research, 16: 751-753.

Mahesh B. and Satish S. (2008). Antimicrobial activity of some important medicinal plants against plant and human 
pathogens. World Journal of Agricultural Science, 4(5): 839-843.

Markham K.R. (1982). Techniques of Flavonoids Identification. Academic Press, New York, USA. pp. 1-113.

Mendoza L, Wilkems M. and Urzua A. (1997). Antimicrobial study of the resinous exudates of diterpenoids and flavonoids isolated from some Chilean Pseudognapluilium (Asteraceae). Journal of Ethnopharmacology, 58: 85-88.

Morita Y., Tomida J. and Kawamura Y. (2013). Responses of Pseudomonas aeroginosa to antimicrobials. Front Microbiology, 4: 422-435.

Nostro A., Germano M.P., D'angelo V., Marina A. and Cannatelli M.A. (2000). Extraction methods and bioautography for evaluation of medicinal plant antimicrobial activity. Letters in Applied Microbiology, 30: 379-384.

Ogundipe O.O., Moody J.O., Fakeye, T.O. and Ladipo, O.B. (2000). Antimicrobial activity of Mallotus oppositifolium extracts. African Journal of Medicinal Science, 29: 281-283.

Oyeleke G.O., Olagunju, E.O. and Ojo A. (2012). Functional and physicochemical properties of watermelon (Citrillus lanatus) seed and seed oil. Journal of Applied Chemistry, 2(2): 29-31.

Pennington J.A.T. and Fisher R.A. (2010). Food component profiles for fruit and vegetable subgroups. Journal of Food Composition and Analysis, 23(5): 41 1-418. Rubatzky V.E. and Yamaguchi M.A. (1997). World Vegetables, Principles, Production and Nutritive Value. 2nd Edition, Chapman and Hall, USA. pp. 577-639.

Silver L.G., Lee, I.S. and Afkinnghorn D.A. (1998). Special Problem with Extraction of Plants in Natural Product Isolation. Human Press Inc. 999, Review Drive, Suite 208 Totowa. pp. 343-364.

Sofowora E.A. (2008). Medicinal Plants and Traditional Medicine in Africa. 3rd ed. Spectrum Books, lbadan. pp. 191-289.

Vandermark J. (2011). The health benefits of watermelon seeds. http:/www./westrong.com/article/24243healthbenefits-watermelon-seeds/. 201811-15.

Varghese S., Narmadha R., Gomathi D., Kalaisevi M. and Devaki K. (2013). Phytochemical screening and HPTLC finger printing analysis of Citrillus lanatus (Thunb.) seed. Journal of Acute Disease, 2(2): 122126.

Vishnoi N.R. (1979). Advanced Practical Chemistry. Yikas Publication House PVT Ltd Ghaziabad- India. pp. 445-449.

Vlkova H., Schlegelova J., Babak V., Jaclic Z., Stosova T. and Saver P. (2008). Resistance to erythromycin of Staphylococcus spp. isolates from food chain. Veterinarni Medicina, 53(6): 307-314. 
Wehner T. (2008). Watermelon in XU, H.X. and Lee, S. (2001). Activity of plant Vegetables 1: Asteraceae, Brassicaceae, flavonoids against antibiotic resistant Chenopodicaceae and Cucurbitaceae. bacteria. Phytotherapeutic Research, 15: Springer, New York. pp. 381-418. 39-43. 